\title{
The Aid to Myanmar, Excercising Power of Indonesia Under Jokowi's Leadership
}

\author{
Alrafsya Mahendra Saputra \\ 2014330110 \\ Mahasiswa Ilmu Hubungan Internasional, Fakultas Ilmu Sosial dan Ilmu Politik \\ Universitas Katolik Parahyangan
}

\begin{abstract}
Semenjak Jokowi mengambil tanggung jawab sebagai presiden Indonesia, Indonesia menjadi negara yang menarik perhatian dunia internasional, dari kebijakan dalam sekaligus luar negerinya yang berinisiatif menjadikan Indonesia poros poros maritim dunia, sampai kepada partisipasinya dalam isu-isu internasional. Salah satu kasus internasional yang sedang menjadi viral adalah kasus Rohingnya, yang menarik perhatian berbagai negara, khususnya negara-negara Asia. Indonesia menjadi salah satu negara yang menjadi sasaran dari pengungsi-pengungsi Rohingnya. Oleh karena itu, Indonesia, di bawah kepemimpinan Jokowi, meminta Myanmar untuk menyelesaikan masalah kemanusiaan dengan Rohingnya. Tidak hanya selesai di situ, Indonesia juga berinisiatif untuk memberikan bantuan. Hal inilah yang menarik perhatian dari penelitian ini, karena dalam memberikan bantuan kemanusiaanya ini, secara tidak langsung Indonesia juga sedang melaksanakan kekuatan negaranya sebagai "Middle Power Countries". Tujuan dari karya tulis adalah untuk memberikan penjelasan bagaimana dari bantuan ini, Indonesia sebagai negara Middle Power mendapat akses dan dapat mengerahkan dampaknya terhadap negara Myanmar, bahkan sampai pengelolaan kebijakan negara Myanmar.
\end{abstract}

Keywords: Jokowi, Rohingnya, Bantuan Kemanusiaan Indonesia, Potensi Akses Indonesia,Politik Luar Negeri Indonesia

\section{Introduction: Origin of The Call}

The president of Indonesia called the government of Myanmar to stop the act of violence against its own people inside their own territories on the night of September 3, 2017. Retno Marsudi, as the representative of Indonesia, went on the evening on the same day. ${ }^{1}$ Indonesia requested the government of Myanmar to give

\footnotetext{
1 "Presiden Jokowi meminta pemerintah Myanmar 'hentikan dan cegah kekerasan'," BBC, September 3, 2017, accessed on April 4, 2018, http://www.bbc.com/indonesia/indonesia41140890
} 
security to all the people, including all the muslim living in their territories, also, Indonesia demanded the government to ease the access for the humanitarian aid towards the muslim people of Myanmar. The task of Retno is not over only to send the humanitarian message toward the government of Myanmar, but she also needs to communicate intensively toward the United Nations and the Advisory Commission on Rakhine State. ${ }^{2}$

The President's call was response of Indonesian governmet towards its citizens crying out through their demonstrations to help the muslim people that came from the Rakhine state. ${ }^{3}$ These demonstrations blasted the act of the Myanmar government to its muslim people, such as the people who called themselves as the Masyarakat Profesional Peduli Rohingya or the Professional Citizen Care for Rohingya burnt the poster with the picture of Aung San Suu Kyi or posted with the words of "The Inhuman Lady". They also demanded that the embassy of the Myanmar to leave Indonesia, and fear by the outcome of the protester that could damage the embassy, polices guarded thet embassy of Myanmar, to ensure its security. ${ }^{5}$ At the same protest, the people who participated were asking the Nobel Peace Prize for Aung San Suu Kyi to be taken back, because of the actual issues that had been happening in Myanmar. The protesters believed that this was not only a religious based act, but this was humanitarian act.. ${ }^{6}$

Even after Jokowi's call on the Myanmar government in stopping their violent action against its people, the people of Indonesia still keep on reminding on the government about the action of the Myanmar government. For example, one day

\footnotetext{
${ }^{2}$ Ibid

${ }^{3}$ Ibid

4 "Di depan Kedutaan Myanmar, demonstran kecam 'kejahatan terhadap Rohingya'," BBC, September 2, 2017, accessed on April 4, 2018, http://www.bbc.com/indonesia/indonesia41134150

${ }^{5}$ Ibid

6 "Indonesian envoy to urge Myanmar to halt violence against Rohingya Muslims," Reuters, September 3, 2017, accessed April 3, 2018, https://www.reuters.com/article/us-myanmarrohingya-indonesia/indonesian-envoy-to-urge-myanmar-to-halt-violence-against-rohingyamuslims-idUSKCN1BEOHS
} 
after the Jokowi's call, September 4, 2017, Indonesian women marched and blasted the action of the slaughtering of the muslim people in Rakhine in front of the gate of the embassy of Myanmar, and by this action they considered this demonstration as the the act of the solidarity. ${ }^{7}$ Also on September 8, 2017, when the islamist group marched towards the Borobudur temple to close its tourism operation as an act of protest of the Rohingya persecution. ${ }^{8}$ It means, from every group in Indonesia, regardless of the internal politics that happened in Indonesia relating to the issue, the government of Indonesia and its citizen agreed in supporting in giving aid to the Rohingya people in the Rakhine state.

The unresolved issue that has become viral in the international world are the Rohingya refugees. These people are scaterred through many regions, and one of them is Indonesia. A group of muslim Rohingya people who lived in Myanmar were persecuted, and discriminated by the other Myanmar people who had different background. One of the example was the burning of the houses that happened in Rakhine state. Instead of helping the Rohingya people, Myanmar officials blamed other parties for this incident. ${ }^{9}$ Moreover, some people in millitary became the perpetrators of the violent action to the people of Rohingya. ${ }^{10}$ This was the reason why people of Rohingya dared to move to the other countries, even by a simple

\footnotetext{
${ }^{7}$ Sutari, Tiara, "Ratusan Perempuan Demo Kedubes Myanmar Kecam Konflik Rohingya," CNN Indonesia, September 4, 2017, accessed on April 3, 2018, https://www.cnnindonesia.com/nasional/20170904105838-20-239252/ratusanperempuan-demo-kedubes-myanmar-kecam-konflik-rohingya 8 "Indonesia to bar protest against Rohingya persecution at Borobudur temple," Channel News Asia, September 5, 2017, accessed on April 4, 2018, https://www.channelnewsasia.com/news/asia/indonesia-to-bar-protest-against-rohingyapersecution-at-9187376

9 "Rohingya Muslims flee as more than 2,600 houses burned in Myanmar's Rakhine," Reuters, September 2, 2017, accessed on April 3, 2018, https://www.reuters.com/article/us-myanmar-rohingya/rohingya-muslims-flee-as-morethan-2600-houses-burned-in-myanmars-rakhine-idUSKCN1BD083

${ }^{10}$ Sidhu, Sandi and Hunt, Katie, "Seven Myanmar soldiers jailed for Rohingya killings uncovered by reporters," CNN, Updated on April 11, 2018, accessed on April 4, 2018, https://edition.cnn.com/2018/04/10/asia/rohingya-myanmar-soldiers-jailedintl/index.html
} 
transportation. Also this was the reason why the case attracted the international world in the aspect of humanity.

Indonesia under Jokowi's leadership has been so active in the international world, especially in responding to the international issues that affected Indonesia, and the president made a determined act based on its respond. For example on how Jokowi responded toward China in the case of Natuna. He ordered Indonesia's military sectors to go to the Natuna region, showing the region belong to Indonesian people. He ordered shot on the ship belonged to China, Han Tan Cou, by Indonesian Warship called the Imam Bonjol. ${ }^{11}$ Although this order create a more tensive relationship between the two countries, Indonesia under Jokowi still wants to have a good relationship with China. ${ }^{12}$ Even though Indonesia under Jokowi have had a determined act, sometimes a tensive act, but still, they wanted to maintain a good relationship with countries related to the issues. In the case of Natuna region, after the shot, Indonesia tried to make a deal with China by using diplomacy as its tool. ${ }^{13}$ The same thing happens when Indonesia respond toward the case of Myanmar, and the other significant aid by Indonesian government toward Myanmar government.

The case of Indonesia's aid toward Myanmar is very unique, because through this aid, Indonesia is not just merely about solving a threat to Indonesia's sovereignity. Indonesia's aid was based of the people's voice to help the Rohingya people who have been persecuted by its own government, this means that the reason of the aid was based on humanitarian cause. Even though this case might be only based on humanitarian means, but at the same time, Indonesia, as a Middle Power country gets benefits indirectly from the action. When this paper talks about

\footnotetext{
${ }^{11}$ Kusumadewi, Anggi, "Rapat di Atas Kapal Perang di Natuna, Jokowi 'Gertak' China," CNN Indonesia, June, 23, 2016, accessed on April 11, 2018, https://www.cnnindonesia.com/nasional/20160623091859-20-140309/rapat-di-ataskapal-perang-di-natuna-jokowi-gertak-china

12 Ibid

${ }^{13}$ Ibid
} 
benefits, it is neither about economic or millitary benefits, but it is about on how Indonesia could influence politically from this aid, such as what the United States had done to the other countries by giving aid. This paper is not stating that Indonesia directly or purposefully, by giving aid to Myanmar, had the aim to influence on the will of the other states, which in this case is Myanmar itself.

\section{The Concept of Middle Power}

Before proceeding to the main argument, this paper would explain the concept of Middle power countries. What distinguish these countries from the lower power countries and even with the greater countries. What action should be considered as the action of the Middle power countries, how they responded and on how they would act based on their respond and their international statement (what they said regarding the international issues that has become the international phenomenon). This categories would help the reader distinguish that Indonesia, under the President Jokowi's leadership, as one of the Middle countries who have the power to exercise its influence.

Taking the conclusion from the book with title "Middle Power in International Politics" by Carsten Holeraad, it defines a lot and gives a good definition on the concept of Middle Power countries. First that could distinguish these countries from the other are the resources they have. Comparing with the lower power countries, these countries would have a better economic environment and its development. Also he quoted from an official of the Canadian Department of External Affairs, R.G Riddell, that said Middle Power countries are

"those which, by reason of their size, their material resources, their willingness and ability to accept responsibility, their influence and their stability are close to being great powers." 14

This means that Middle Power countries also, can be defined, as a potential countries in terms of power with potential resources. From the same quote that was

\footnotetext{
${ }^{14}$ Holeraad, Carsten, Middle Powers In International Politics, 68
} 
taken by Ridell, it means the willingness of these countries to take action in the interntional affairs (rephrasing from the words of the quote :willingness and ability to accept responsibility) could be the indicators action that involving, interferring, or aiding in the international affairs as the an action of the higher level countries than the developing countries. ${ }^{15}$ Since without willingness to take action, other countries would not acknowledge its power. Also, the book states that another indicators are the power of the millitary such as the power of their nuclear and the number of its armies available. ${ }^{16}$

Rephrasing from the the book, it can be concluded, and logically saying, that those countries which have more resources in terms of economic, millitary, or even stability, could exercise its power in the international politics since they have more resources or maybe when they are just being confident with the resources (this means they might take action in the international politics, though their actual condition is not in a good shape, such as political stability or high rate of poverty, for example, India). From exercising its power and resources, it can be said that these countries at least got the acknowledgement from the other countries, puposefully or not. Positive or negative effect, these countries would be acknowledged its power. And, by this it would effecting other countries such as influencing other countries' action, decision, and even enhancing diplomacy and its international relation.

\section{The Indonesia's Aid To Myanmar}

When the book said about the willingness to accept responsibility, Indonesia really had fulfilled and fit into the category of taking the responsibility. It has been known that the Rakhine state in a desperate condition, too many casualties such as the burning of the houses and the lost of lives of the Rohingya people. Indonesia is said to be the one who willingly to aid Myanmar in solving the

\footnotetext{
${ }^{15} \mathrm{Ibid}$

${ }^{16} \mathrm{Ibid}$
} 
Rohingya crisis. According to Suu Kyi, the leader of Myanmar, there are some aid project that proposed by Jokowi in Myanmar in order to decrease the crisis and the feel of being discriminated by the government, and their aspects are; health program, education program, and for the livelihood program ${ }^{17}$. It can be concluded that through these programs, Indonesia purposefully attracts the people or the refugees of the Rohingya to come back to the land of Rakhine. Also, what Indonesia did was to fulfill the very basic needs of the Rohingya people, before proceeding to the other projects.

In the aspect of health, Indonesia made hospitals for the people of Rakhine especially for the people of the Rohingya. The help does not only come from the organization but also some organizations, NGOs, and even the private sectors contributed as well in the construction. For the private sectors, the government of both Indonesia and Myanmar offered to Indonesia investor to invest in Indonesia. ${ }^{18}$ This construction has started since September 2017. To ease and make better efficiency, Indonesia used the local contractors and the local material. Also through this hospitals, people would get a better job to survive, those people could work in the hospitals or as the contractors. ${ }^{19}$ It means this also would enhance and help the economy of the people of Rakhine and the surroundings, which is very crucial to asserts the need of the people. This is to show on how Indonesia had wanted to

\footnotetext{
17 "Jokowi dan Suu Kyi bahas perdamaian dan pembangunan rumah sakit di Rakhine," BBC, April 29, 2017, accessed on April, 23, 2017, http://www.bbc.com/indonesia/indonesia39754541

18 "Pengusaha Indonesia dan Myanmar jajaki peluang bisnis," Antara News, September 30, 2017, accessed on May 19, 2018.

https://www.antaranews.com/berita/655638/pengusaha-indonesia-dan-myanmar-jajakipeluang-bisnis

${ }^{19}$ Asril, Sabrina, "Indonesia Mulai Bangun Rumah Sakit di Rakhine, Myanmar"," Nasional Kompas, November 20, 2017, Accessed on April 23, 2017, https://nasional.kompas.com/read/2017/11/20/15285611/indonesia-mulai-bangunrumah-sakit-di-rakhine-myanmar
} 
show commitment and its solidarity from Indonesia's government and its people toward Myanmar and the Rakhine state. ${ }^{20}$

In terms of education, Indonesia had make schools for the Myanmar people, especially for the refugees. They have make two buildings with capacity of three hundred students to attend in the school. The reason is because that the people of Rohingya have the low level of educational skills and information. ${ }^{21}$ On September 13, 2017, President Jokowi officially also send other humanitarian help to the people of Rohingya, such as Shelter Tent, Portable Water Tank, Fast Food, Special food for pregnant women and toddlers, medicines, and sarongs. ${ }^{2223}$ This will help the short term aid for the people, Indoneisa focus not only in the terms of projects but also the short terms needs of what the people needs, since they are in crisis.

\section{Reason for The Act and The Potential from The Act}

One of the reason that the aid of Indonesia could gain in having the access in Myanmar territory was because of what Jokowi had done for the Myanmar government, on how Jokowi sow the the relationship with the Myanmar government previosly. He made a move previouslyin terms of economic and development toward Myanmar, especially the Rakhine state. Jokowi made an economic help which is to open Myanmar for the foreign investors especially those

\footnotetext{
20 "Construction of Indonesian Hospital in Rakhine State Begins," Ministry of Foreign Affairs Republic of Indonesia, November 20, 2017, accessed on April 23, 2018 https://www.kemlu.go.id/en/berita/berita-perwakilan/Pages/Construction-of-IndonesianHospital-in-Rakhine-State-Begins.aspx

${ }^{21}$ Bonasir, Rohmatin, "Sekolah bantuan Indonesia diharapkan jadi titian perdamaian di Myanmar," BBC, January 11, 2017, accessed on April 23, 2018, http://www.bbc.com/indonesia/dunia-38583864

22 "Government of Myanmar Appreciates Indonesia's Humanitarian Aid," Ministry Of Foreign Affairs Republic Of Indonesia, September 25, 2017, accessed on April 24, 2018, https://www.kemlu.go.id/en/berita/Pages/Government-of-Myanmar-AppreciatesIndonesia\%E2\%80\%99s-Humanitarian-Aid.aspx 23 "Diangkut empat pesawat Hercules, RI kirim bantuan kemanusiaan untuk Rohingya," BBC News Indonesia, September 13, 2017, accessed on May 19, 2018 http://www.bbc.com/indonesia/indonesia-41250030
}

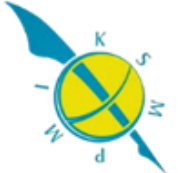


investment that come from Indonesia. Specifically saying, Jokowi urged these investors to invest focused on these three sectors; mining, telecommunication, and infrastructure. ${ }^{24}$ Also in this cooperation, what Jokowi tried to aim is to develop and prepare skilled workforce, for example skilled construction workers are ready to be sent to Myanmar on the project. ${ }^{25}$ This cooperation was said quite being contributive toward the relationship of Indonesia and Myanmar. ${ }^{26}$

This could also means, that through this action, Indonesia could gain more trust from Myanmar. And from this indonesia could enhance international relation with Myanmar, for example on how now that Indonesia made a better cooperation on terrorism, both of the parties would make the Memorandum Of Understanding on tackling the terrorrism. This cooperation could happen reasoned by the contribution of Indonesia towards the crisis of Rohingya refugees. ${ }^{27}$

Taking further side effect of this aid, Indonesia now could gain access toward influencing the government of Myanmar. Thus the example is on the Indonesian school itself, here, the school would teach their students on how to be more tolerant to other people with background. ${ }^{28}$ Moreover, what indonesia's aim is not only to the people, but they aimed to change the people's perspective on the government side, with their aid, they tend to give a better comprehension on helping

\footnotetext{
24 "Jokowi Urges Indonesian Investors to Invest in Myanmar," Tempo, November 12, 2014, accessed on April 24, 2018, https://en.tempo.co/read/news/2014/11/12/056621489/Jokowi-Urges-IndonesianInvestors-to-Invest-in-Myanmar 25 Ibid

${ }^{26}$ Putranto, Algooth, “Misi Menlu Retno, Upaya Jokowi Meneruskan Tradisi Indonesia," Kompas, September 5, 2017, accessed April 24, 2018, https://nasional.kompas.com/read/2017/09/05/17384481/misi-menlu-retno-upayajokowi-meneruskan-tradisi-indonesia ${ }^{27}$ Saraswati, Patricia, "Indonesia dan Myanmar Jalin Kerja Sama Hadapi Terorisme," CNN Indonesia, Desember 12, 2017, accessed on April 24, 2018, https://www.cnnindonesia.com/nasional/20171216075405-20-262797/indonesia-danmyanmar-jalin-kerja-sama-hadapi-terorisme ${ }^{28}$ Bonasir, Rohmatin, "Sekolah bantuan Indonesia diharapkan jadi titian perdamaian di Myanmar," BBC Indonesia, Januari 11, 2017, accessed on April 24, 2018, http://www.bbc.com/indonesia/dunia-38583864
} 
the government about democracy and governance. ${ }^{29}$ When people talk about governance, it means they will share and comment on the current governance, this is what Indonesia tried to do to Myanmar, helping to make Myanmar in using a better governance.

In conclusion of all, as a Middle Power countries with a potential and fine resources, Indonesia under Jokowi leadership, tried to exercise its power. From the contribution of what Indonesia had proposed to the Myanmar on investing, which from this we know that Indonesia contributing towards the economy of Myanmar to the aid made to Myanmar, it helps Indonesia in asserting its active contribution toward international politics and issues to be acknowledged of its resources and willingness with potential, economic, size of people who demanded Indonesia to aid Myanmar, and the contribution of Millitary in the aid. The side effect of all these are that Indonesia could gain more of trust and access from and to Myanmar. Regardless of purposefully or non- purposefully tendency, Indonesia could increase more of its influence towards Myanmar.

\section{Bibliography}

"Construction of Indonesian Hospital in Rakhine State Begins." Ministry of Foreign Affairs Republic of Indonesia. November 20, 2017. accessed on April 23, 2018. https://www.kemlu.go.id/en/berita/beritaperwakilan/Pages/Construction-of-Indonesian-Hospital-in-Rakhine-StateBegins.aspx

"Diangkut empat pesawat Hercules, RI kirim bantuan kemanusiaan untuk Rohingya.” BBC News Indonesia. September 13, 2017. accessed on May 19 2018. http://www.bbc.com/indonesia/indonesia-41250030

\footnotetext{
29 "Indonesian Humanitarian Aid a Form of Constructive Support for Inclusive Development in Rakhine State," Ministry Of Foreign Affairs Republic Of Indonesia, Januari 22, 2017, accessed on 24 April 2018, https://www.kemlu.go.id/en/berita/Pages/indonesianhumanitarian-aid-form-constructive-support-inclusive-development-rakhine.aspx
} 
"Di depan Kedutaan Myanmar, demonstran kecam 'kejahatan terhadap Rohingya'."

BBC, September 2, 2017. accessed on April 4, 2018. http://www.bbc.com/indonesia/indonesia-41134150

“Government of Myanmar Appreciates Indonesia’s Humanitarian Aid.” Ministry Of Foreign Affairs Republic Of Indonesia. September 25, 2017. accessed on April 24, 2018. https://www.kemlu.go.id/en/berita/Pages/Government-ofMyanmar-Appreciates-Indonesia\%E2\%80\%99s-Humanitarian-Aid.aspx

"Indonesian envoy to urge Myanmar to halt violence against Rohingya Muslims." Reuters, September 3, 2017. accessed April 3, 2018. https://www.reuters.com/article/us-myanmar-rohingya-indonesia/indonesianenvoy-to-urge-myanmar-to-halt-violence-against-rohingya-muslimsidUSKCN1BE0HS

"Indonesian Humanitarian Aid a Form of Constructive Support for Inclusive Development in Rakhine State.” Ministry Of Foreign Affairs Republic Of Indonesia. Januari 22, 2017. accessed on 24 April 2018. https://www.kemlu.go.id/en/berita/Pages/indonesian-humanitarian-aid-formconstructive-support-inclusive-development-rakhine.aspx

"Indonesia to bar protest against Rohingya persecution at Borobudur temple." Channel News Asia. September 5, 2017. accessed on April 4, 2018. https://www.channelnewsasia.com/news/asia/indonesia-to-bar-protest-againstrohingya-persecution-at-9187376

"Jokowi dan Suu Kyi bahas perdamaian dan pembangunan rumah sakit di Rakhine.” BBC. April 29, 2017. accessed on April, 23, 2017. http://www.bbc.com/indonesia/indonesia-39754541

"Jokowi Urges Indonesian Investors to Invest in Myanmar." Tempo. November 12, 2014. accessed on April 24, 2018. https://en.tempo.co/read/news/2014/11/12/056621489/Jokowi-UrgesIndonesian-Investors-to-Invest-in-Myanmar

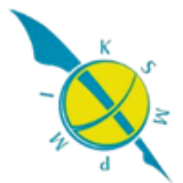


"Pengusaha Indonesia dan Myanmar jajaki peluang bisnis." Antara News. September 30, 2017. accessed on May 19, 2018. https://www.antaranews.com/berita/655638/pengusaha-indonesia-danmyanmar-jajaki-peluang-bisnis

"Presiden Jokowi meminta pemerintah Myanmar 'hentikan dan cegah kekerasan'." BBC, September 3, 2017. accessed on April 4, 2018. http://www.bbc.com/indonesia/indonesia-41140890

"Rohingya Muslims flee as more than 2,600 houses burned in Myanmar's Rakhine." Reuters. September 2, 2017. accessed on April 3, 2018. https://www.reuters.com/article/us-myanmar-rohingya/rohingya-muslims-fleeas-more-than-2600-houses-burned-in-myanmars-rakhine-idUSKCN1BD083

Sutari, Tiara. "Ratusan Perempuan Demo Kedubes Myanmar Kecam Konflik Rohingya." CNN Indonesia. September 4, 2017. accessed on April 3, 2018. https://www.cnnindonesia.com/nasional/20170904105838-20-239252/ratusanperempuan-demo-kedubes-myanmar-kecam-konflik-rohingya

Asril, Sabrina. "Indonesia Mulai Bangun Rumah Sakit di Rakhine, Myanmar"." Nasional Kompas. November 20, 2017. Accessed on April 23, 2017. https://nasional.kompas.com/read/2017/11/20/15285611/indonesia-mulaibangun-rumah-sakit-di-rakhine-myanmar

Bonasir, Rohmatin. "Sekolah bantuan Indonesia diharapkan jadi titian perdamaian di Myanmar.” BBC. January 11, 2017. accessed on April 23, 2018. http://www.bbc.com/indonesia/dunia-38583864

Kusumadewi, Anggi. "Rapat di Atas Kapal Perang di Natuna, Jokowi 'Gertak' China." CNN Indonesia. June, 23, 2016. accessed on April 11, 2018. https://www.cnnindonesia.com/nasional/20160623091859-20-140309/rapat-diatas-kapal-perang-di-natuna-jokowi-gertak-china

Holeraad, Carsten, Middle Powers In International Politics, 68

Putranto, Algooth. "Misi Menlu Retno, Upaya Jokowi Meneruskan Tradisi Indonesia.” Kompas. September 5, 2017. accessed April 24, 2018. 
https://nasional.kompas.com/read/2017/09/05/17384481/misi-menlu-retnoupaya-jokowi-meneruskan-tradisi-indonesia

Saraswati, Patricia. "Indonesia dan Myanmar Jalin Kerja Sama Hadapi Terorisme.” CNN Indonesia. Desember 12, 2017. accessed on April 24, 2018. https://www.cnnindonesia.com/nasional/20171216075405-20262797/indonesia-dan-myanmar-jalin-kerja-sama-hadapi-terorisme

Sidhu, Sandi and Hunt, Katie. "Seven Myanmar soldiers jailed for Rohingya killings uncovered by reporters." CNN. Updated on April 11, 2018. accessed on April 4, 2018. https://edition.cnn.com/2018/04/10/asia/rohingya-myanmarsoldiers-jailed-intl/index.html 